\title{
Effects of monetary policy transmission mechanism on car sales in Brazil after the real plan
}

\author{
Efeitos do mecanismo de tranmissão de política monetária sobre as \\ vendas de automóveis no Brasil pós-plano Real
}

\author{
Thiago Rocha Fernandes ${ }^{1}$ (D), Fabiano da Costa Dantas ${ }^{2}$ \\ 1Universidade Federal Rural do Semi-árido - UFERSA, Caraúbas, RN, Brasil. E-mail thiago_678@hotmail.com \\ 'Universidade Federal Rural do Semi-árido - UFERSA, Centro Multidisciplinar de Caraúbas, Depto de Ciência e \\ Tecnologia, Caraúbas, RN, Brasil. E-mail fabianodantas@ufersa.edu.br
}

How to cite: Fernandes, T. R., \& Dantas, F. C. (2020). Effects of monetary policy transmission mechanism on car sales in Brazil after the real plan. Gestão \& Produção, 27(2), e3780.

https://doi.org/10.1590/0104-530X3780-20

\begin{abstract}
The study aims to evaluate the effects of monetary policy transmission mechanism in car sales in Brazil, after the Real Plan. The representativeness of the auto industry in the Brazilian economy is significant. Therefore, to provide an analysis of the actions of monetary policies on car sales is essential to define schedules in the industry. Thus, the methodology been based on the use of Vector Auto Regressive (VAR) with a Vector Error Correction Model (VECM), supported by econometric tests. The results showed that there is a relationship of monetary policy actions in car sales in Brazil.
\end{abstract}

Keywords: Monetary policy; Vector Error Correction (VEC); Automobile industry.

Resumo: O trabalho tem por objetivo avaliar os efeitos do mecanismo de transmissão de política monetária nas vendas de automóveis no Brasil, pós-Plano Real. A representatividade da indústria automobilística na economia brasileira é significativa. Diante disso, prover uma análise das ações de políticas monetárias sobre as vendas de automóveis é imprescindível para a definição de planeamentos no setor. Assim, a metodologia baseou-se no uso de Vetor Auto Regressivo (VAR) com um modelo Vetor de Correção de Erros (VEC), suportado por testes econométricos. Os resultados apontaram que há uma relação das ações de política monetária nas vendas de automóveis no Brasil.

Palavras-chave: Política Monetária; Vetor com Correção de Erro (VEC); Indústria Automobilística.

\section{Introduction}

In order to stop the long process of high inflation that has intensified since the mid-1980s in the Brazilian economy, been implemented in 1994, the Real Plan. The steps of the Plan can been summarized as follows: i) achieving fiscal adjustment short term - with the creation of the Immediate Action Plan and the Emergency Social Fund; ii) de-indexation of the economy through a monetary reform - creating a fully indexed unit of account, the Real Value Unit (RVU), later transformed into currency, the Real, which replaced the

Received Jan. 5, 2017 - Accepted Aug. 31, 2017

Financial support: None 
Cruzeiro Real; and iii) the use of fixed exchange rate - characterized by the maintenance of the Real artificially overvalued by the Central Bank of Brazil (BCB) (Modenesi, 2010).

According to Modenesi (2010) during the Real implementation period, monetary policy been conducted in order to control the volume of international reserves. In 1998-99, Brazil's economy suffered a speculative attack that culminated in the replacement of the fixed exchange rate Regime by Inflation Targeting (RMI). Despite the fears of many, the overshooting of the exchange rate did not result in the return of inflation and stability been preserved.

In the period from 1995 to 2008 , monetary policy been marked by excessive rigidity, which remained even after the consolidation of price stability and the implementation of RMI. The real interest rate in Brazil was systematically and considerably higher than that prevailing in emerging countries. Except for the years, 2001 and 2002, interest in the country were higher than those recorded in the group of emerging countries do (Modenesi, 2010).

In the same period of the Real Plan, the automobile industry was undergoing restructuring due to economic changes in Brazil. Between 1991 and 1993, annual investments of the Brazilian automobile industry recorded an increase of $3 \%$. In later years, the expectation of the sector was higher growth, which would lead to the need to expand production, including new plants (Santos \& Burity, 2002).

Even with growth expectations supported by the Real Plan, the increased investment in automobile production capacity were timid and insufficient. Then, in 1995, the Federal Government announced an industrial policy aimed at this segment and thus enabled a new wave of investment in infrastructure (Casotti \& Goldenstein, 2008).

According to Casotti \& Goldenstein (2008), after the year 1997, when the national consumption reached a record 2 million vehicles sold, growth expectations were frustrated. Crisis in the international economy rebounded strongly in the country, which led to a significant increase in interest rates. The market for automotive vehicles reduced, precisely at the time that the announced investments being completed. Were several years in a row in which both assemblers and the suppliers of auto parts soured heavy losses, since it had invested its resources in capacity. After the 1997 record, sales fell to about 1.3 million in 1999.

At the beginning of this century, the energy crisis, promised industrial growth and pessimism of the automobile industry reached idleness rates of $50 \%$ of production; a reduction in sales, causing a decrease in investments of 35\% between 2001 and 2005 (Casotti \& Goldenstein, 2008).

Given these aspects, this study aims to evaluate the effects of the monetary policy transmission mechanisms on car sales in Brazil in the period from January 1995 to December 2014.

The structure of this study been divided into five sections, besides this introduction, in section 2, monetary policy and its mechanisms will be demonstrated. Section 3 discussed the applied method. Finally, in the remaining sections will be exhibited the expected results, conclusions, references, and annex respectively.

\section{Monetary policy and its mechanisms}

According to the Central Bank of Brazil (BACEN, 1999) themain, monetary policy transmission channels are interest rates, exchange rates, asset prices, credit and expectations. By affecting these variables, monetary policy decisions influence on the 
levels of savings, investment and expenditure of individuals and companies, which in turn affect aggregate demand and, finally, the rate of inflation.

Each monetary policy transmission channel effect on inflation. From a monetary shock, changes occur in decisions on investments, savings, and consumer durables and in net exports, however, monetary policy has real effects only in the short and medium term, or long-term money is neutral. The sole effect in the end is about the price level of the economy (BACEN, 1999).

According to Mendonça (2001), the best-known transmission channel of monetary policy is the interest rate. In this channel, the action of monetary policy can be understood as follows: the Central Bank conducts a monetary contraction (M $\downarrow$ ); with a smaller amount of money available in the economy, there is an increase in interest rates very short term ( $\mathrm{i} \uparrow$ ); as a result, it is assumed that there is price rigidity, and the real interest rate also increases $(r \uparrow)$. Due to the real return from the interest become higher than the marginal efficiency of capital in part of the economy, has resulted in a reduction in the level of investment $(I \downarrow)$, which, in turn, results in a drop in aggregate demand and the consequent decrease in output $(Y \downarrow)$. The scheme been depicted as follows:

$M \downarrow \rightarrow i \uparrow \rightarrow r \uparrow \rightarrow I \downarrow \rightarrow Y \downarrow$

Another monetary policy transmission channel is the exchange rate when the economy takes a floating exchange rate regime and free movement of capital. According to Barboza (2015), a monetary contraction ( $\mathrm{M} \downarrow$ ) causes the increase in the interest rate ( $\mathrm{i} \uparrow$ ) causing capital inflows into the economy, due to gains opportunities in domestic assets, which leads to rate appreciation exchange $(E \downarrow)$. Whereas there was no variation in domestic and foreign prices in the same period, the real exchange rate appreciation also suffers (e $\downarrow$ ), which implies lower competitiveness of domestic products, since in relative terms, the price of domestic product became if higher than abroad. The result of this process is the reduction in the level of net export (NX $\downarrow$ ) leading to a reduction product $(\mathrm{Y} \downarrow)$.

$M \downarrow \rightarrow i \uparrow \rightarrow E \downarrow \rightarrow e \downarrow \rightarrow N X \downarrow \rightarrow Y \downarrow$

A third channel mechanism could been called price channel assets, and can be divided by its effect by two means. The first is the corporate investment decision, which is by evaluating the relationship between the market value of a company and its replacement cost of capital, defined by Tobin's q. The higher this ratio, the greater the incentive for companies to invest because they consider that its ability to generate cash flows captured by the perception of its value is largest market in relation to its replacement cost (Tomazzia \& Meurer, 2009).

A second half of the asset price channel affects consumption decisions of households the change in their wealth. This means the channel been based on the theory of Modigliani's life cycle, in that the consumer spending is softened throughout life, and a reduction of the present and future wealth of households is offset by a reduction in present consumption.

Thus, according to Mendonça (2001), the effects from a monetary contraction can understand the connection between monetary policy and the stock price. With the decrease in the money supply, the agents have less money, which leads to a reduction 
in expenditure. Thus, due to the lower volume of funds, the stock market also suffers a negative impact on the absorption of assets. The monetary contraction raises the interest rate, making the bonds more attractive than stocks, which consequently leads to a reduction in the stock price $\left(P_{A} \downarrow\right)$. Therefore, there is a drop in Tobin's $q(q \downarrow)$ which leads to a lower level of investment in the economy and the consequent decrease in output $(Y \downarrow)$. The schematic form been represented as follows:

$$
M \downarrow \rightarrow i \uparrow \rightarrow P_{A} \downarrow \rightarrow q \downarrow \rightarrow I \downarrow \rightarrow Y \downarrow
$$

The other channel of the monetarist vision for the transmission of the stock price occurs through the wealth effect on consumption. From this design, saving plays a key role for a stable consumption because it allows consumers to move income of periods that is higher for the periods in which it is lower. From this perspective, consumers' income may be broken down into three basic components: i) human capital; ii) real capital; and iii) financial wealth. In general, the main component of financial wealth is the level of stocks held by the public. When the stock price falls, the value of financial wealth decreases (RF $\downarrow$ ) and therefore the resources of consumers over the life decrease, which indicates a likely decline in consumption (C $\downarrow$ ) (Mendonça, 2001). In this way:

$$
M \downarrow \rightarrow i \uparrow \rightarrow P_{A} \downarrow \rightarrow R F \downarrow \rightarrow C \downarrow \rightarrow Y \downarrow
$$

Another monetary transmission channel is the credit channel. Which according to Barboza (2015) transmits the monetary policy impulses toward the real economy via changes in the price of credit and can been understood by the other two transmission channels: the bank-lending channel and the channel swings. In the first case, commercial banks play special role in the financial system due to the ability to restrict credit to some borrowers, especially for small businesses. The same is not true for the case of large companies, because they can get direct access to the credit market via stock and bond markets. Thus, a monetary policy contraction in aggregate demand causes a rise in the interest rate ( $\mathrm{i} \uparrow$ ) leading to reduction of reserves and bank deposits $\left(R_{B}\right.$ and $\left.D_{B} \downarrow\right)$ these financial losses make them more cautious banks in their lending policies, which culminates with the reduction in the volume of loans granted by banks $\left(E_{B} \downarrow\right)$. Thus, with fewer resources available, there tends to be a reduction in the level of investment $(I \downarrow)$, and consequently a reduction in the product. Schematically, the effect is as follows:

$$
M \downarrow \rightarrow i \uparrow \rightarrow R_{B} \downarrow \& D B \downarrow \rightarrow E_{B} \downarrow \rightarrow I \downarrow \rightarrow Y \downarrow
$$

The subsequent transmission channel is the channel balances. Which according to Mendonça (2001), lower net income means that lenders have less collateral for their loans and therefore the possible losses arising from adverse selection are high (SA $\uparrow$ ). Thus, the volume of funds available to borrowers to finance new investments been reduced $\left(R_{E} \downarrow\right)$. It is observed that the moral hazard problem tends to increase (RM $\uparrow$ ), for the reduction in value of the shares, there is one of the business owners the incentive to seek new investment projects that have a higher risk, which therefore 
denotes greater chance of not meeting payments. From this perspective, a monetary contraction causes an increase in interest rates and a decline in the stock price (PA $\downarrow$ ) which implies a lower volume of resources available for investment and a fall in aggregate demand. In this way:

$M \downarrow \rightarrow i \uparrow \rightarrow P A \downarrow \rightarrow S A \uparrow \& R M \uparrow \rightarrow R_{E} \downarrow \rightarrow I \downarrow \rightarrow Y \downarrow$

If considered the monetarist perspective, it is observed that the increase in interest rates $(\mathrm{i} \uparrow$ ) causes deterioration in the balance sheet of the companies due to reduced cash flow (FC $\downarrow$ ). Thus, a new layout for the balance sheet channel can be establishe as:

$M \downarrow \rightarrow i \uparrow \rightarrow F C \downarrow \rightarrow S A \uparrow \& R M \uparrow \rightarrow R_{E} \downarrow \rightarrow I \downarrow \rightarrow Y \downarrow$

Still on the relationship between the credit channel and business spending, Mendonça (2001) considers it appropriate to analyze the credit channel on consumer spending. When you expect a fall in stock prices, the value of financial assets tends to suffer a decline (VAF $\downarrow$ ), which implies greater probability of a financial crisis (CF $\uparrow$ ). Thus, before a financial position that is not safe, consumers tend to reduce the level of consumption $(C \downarrow)$, so that the product of economy decrease $(\downarrow Y)$. Schematically, we have:

$M \downarrow \rightarrow i \uparrow \rightarrow P_{A} \downarrow \rightarrow V A F \downarrow \rightarrow C F \uparrow \rightarrow C \downarrow \rightarrow Y \downarrow$

The fifth and last channel to been analyzed with respect to the channel of expectations. According to Pacheco (2006), the impact of monetary policy actions depends on the extent that individuals and financial markets anticipate them, so it can been said that this channel is present in all channels described above, in that the specific mechanisms to channel expectations are temporary versions of static channels in interest rates, asset prices and credit.

According to Mendonça (2001), when the Central Bank of Brazil changes the interest rate, the expectations of economic agents regarding the evolution present and future of the economy may change. Thus, an increase in interest rates in an attempt to prevent an increase in inflation because recessionary effects in the short term $\left(Y_{\text {ct }} \downarrow\right)$, however, the Central Bank can restore confidence in the future performance of the economy (CDFE $\uparrow$ ) causing rates the expected rate of medium and long term is smaller $\left(\mathrm{i}_{\mathrm{mt}}^{\mathrm{e}} \& \mathrm{i}_{\mathrm{It}} \downarrow\right)$.

Therefore, it is expected that in the long term negative effect on the product arising from an increase in interest rate $(i \uparrow)$ to prevent inflation process is reversed; and that, with the recovery of normality, to be generated in the long term, a stimulus to investment ( $\left.\mathrm{l}_{\mathrm{lt}} \uparrow\right)$ capable of promoting an increase in output $\left(\mathrm{Y}_{\mathrm{It}} \uparrow\right)$. Thus, the channel scheme of expectations been divided into two phases:

1st phase: $M \downarrow \rightarrow i \uparrow \rightarrow r \uparrow \rightarrow I_{c t} \downarrow \rightarrow Y_{c t} \downarrow$; and

2nd phase: CDFE $\uparrow \rightarrow i^{e}{ }_{m t} \& i^{e}{ }_{l t} \downarrow \rightarrow I_{l t} \uparrow \rightarrow Y_{l t} \uparrow$

Mendonça (2001) points out that the literature on the monetary transmission mechanism does not consider the channel of expectations as one of the most important (due to the inherent uncertainty of the effects of monetary policy and the evolution of 
the economy), the Central Bank of Brazil uses monetary policy assuming that the channel of expectations is fundamental in the Brazilian case.

\section{Method}

Data collection been based on information derived from the database arising from the Central Bank of Brazil, the idealization of monetary policy and the resulting data of the National Association of Vehicle Manufacturers (ANFAVEA), the analysis of car sales in Brazil in the period monthly from January 1995 to December 2014.

\subsection{Variables}

The variables that been used in the study to assess the impact of the monetary policy transmission mechanism in the automotive industry were based on studies of Tomazzia \& Meurer (2009), Fernandes \& Toro (2005) and Barboza (2015), which are:

- New Car Sales (V): The quantity of domestic automotive units and licensed imported - Produced units;

- Monetary Aggregate (M1): This variable is linked to the means of payment in which represent the amount of currency that is held by the public coupled with deposits in both private banks and the state in real terms - Average Balances Diaries (R\$ Million / General Price Level);

- Internal Price Index (IPCA): Measures the level of Brazilian inflation related to a range of products and services in the retail market, associated with consumption of households that have income between 1 and 40 minimum wages - IPCA - General - Index (dec. 1993 = 100);

- Real Effective Exchange Rate (TXC): It is the representation of the measure of the competitiveness of Brazilian exports calculated by the weighted average parity index in the purchasing power of the 16 largest trade partners of Brazil. The purchasing power parity is defined by the ratio between the nominal exchange rate ( $R \$$ / unit of foreign currency) and the relationship between Price Index Wholesale (IPA) of the country in the event and the National Price Index consumer (INPC / IBGE) of Brazil;

- Real Rate of Interest (TXJ): It is the reference rate applied in federal bonds in payment transactions, restitution, compensation or reimbursement of government bonds - Interest rate - Over / Selic - Withdrawal inflation in the same period (\% each year).

Thus, we have $t=252$ observations and $n=5$ macroeconomics variables. The variables that did not have seasonality in their series were been seasonally adjusted using the $\mathrm{X}-11$ multiplicative method.

\subsection{Empirical model}

After collecting data, will been used econometric tools for the analysis of the factors and economic indicators and relates it to the objectives of the article, one of the methods chosen for encoding data are Vectors Auto Regressive (VAR) that examine the relationship linear between variables and the lagged values of all its variables and 
it even using constraints as the structure of the economy with regard to the choices of the variables and the number of lags that are included among the variables (BACEN, 2004).

The use of VAR in the analysis of monetary policy is quite common in academic papers.

According to Enders (1995) a VAR model can be described as according to Equation 1:

$$
x_{t}=A_{0}+\sum_{j=1}^{k} A_{j} x_{t-j}+B_{0}+\sum_{j=l}^{k} B_{j} z_{t-j}+\varepsilon_{t}
$$

Where $x_{t}$ is a vector $n \times 1$ that includes the endogenous variables of the model; $A_{0}$ is a vector $n \times 1$ vector interception; $A_{1}, \ldots, A_{j}$ are $n \times n$ matrices of coefficients associated lagged values of endogenous variables to their current values; $B_{0}, \ldots, B_{j}$ are $n \times n$ matrices of coefficients associated current values and lagged exogenous variables to current values of endogenous variables and $\varepsilon_{t}$ is a vector $n \times 1$ of random disturbances IID $\sim \mathrm{N}\left(0, \sigma^{2}\right)$.

Thus, the VAR model applied to this work follows the following algebraic expression (Equation 2):

$$
\begin{aligned}
& V_{t}=A_{1}+\sum_{j=1}^{k} \alpha_{j} V_{t-j}+\sum_{j=1}^{k} \beta_{j} M I_{t-j}+\sum_{j=1}^{k} \lambda_{j} I P C A_{t-j}+\sum_{j=1}^{k} \delta_{j} T X C_{t-j}+\sum_{j=1}^{k} \gamma_{j} T X J_{t-j}+\varepsilon_{l t} \\
& M I_{t}=A_{2}+\sum_{j=1}^{k} \varphi_{j} V_{t-j}+\sum_{j=1}^{k} \omega_{j} M I_{t-j}+\sum_{j=1}^{k} v_{j} I P C A_{t-j}+\sum_{j=1}^{k} \mu_{j} T X C_{t-j}+\sum_{j=1}^{k} \pi_{j} T X J_{t-j}+\varepsilon_{2 t} \\
& I P C A_{t}=A_{3}+\sum_{j=1}^{k} \zeta_{j} V_{t-j}+\sum_{j=1}^{k} \sigma_{j} M I_{t-j}+\sum_{j=1}^{k} \psi_{j} I P C A_{t-j}+\sum_{j=1}^{k} \xi_{j} T X C_{t-j}+\sum_{j=1}^{k} \theta_{j} T X J_{t-j}+\varepsilon_{3 t} \\
& T X C_{t}=A_{4}+\sum_{j=1}^{k} \phi_{j} V_{t-j}+\sum_{j=1}^{k} \vartheta_{j} M I_{t-j}+\sum_{j=1}^{k} \rho_{j} I P C A_{t-j}+\sum_{j=1}^{k} \varsigma_{j} T X C_{t-j}+\sum_{j=1}^{k} \beta_{j} T X J_{t-j}+\varepsilon_{4 t} \\
& T X J_{t}=A_{5}+\sum_{j=1}^{k} \chi_{j} V_{t-j}+\sum_{j=1}^{k} \varphi_{j} M I_{t-j}+\sum_{j=1}^{k} \Omega_{j} I P C A_{t-j}+\sum_{j=1}^{k} \Psi_{j} T X C_{t-j}+\sum_{j=1}^{k} \eta_{j} T X J_{t-j}+\varepsilon_{5 t}
\end{aligned}
$$

Where $\mathrm{V}$ is the number of monthly car sales in Brazil; M1 refers to the monetary aggregate; IPCA is the Brazilian price index; TXC matches the real effective exchange rate; TXJ refers to real interest rate; $A$ is the interception of the functions, $k$ is the number of lags, $t$ is the period analyzed, $j$ is the time lag and $\varepsilon$ is the stochastic term. The series of procedure shall apply in logarithm therefore LNV; LNM1; LNIPCA; LNTXC and LNTXJ.

To identify a long-run relationship between the times series is required, there is an order selection criteria. This is due to the possibility of time series are cointegrated, in a period of long run, even if the cointegration tests does not show this relationship in a shorter period.

To detect the stationarity of the series will use the unit root test with structural break developed by Saikkonen \& Lütkepohl (2002) and Lanne et al. (2002, 2003), in which the structural breaks may occurs in over a number of periods and exhibits a smooth transition to a new level.

Despite regressions dealing with variables that depend on each other, this does not mean that a variable necessarily cause the other. For that will be use test for Granger non-causality proposed by Toda \& Yamamoto (1995), which consists of applying a Wald test to check the restrictions of the parameters of VAR model $\left(k+e_{\max }\right)$, increased 
levels, through an asymptotic chi-squared distribution $\left(x^{2}\right)$, regardless of the system and cointegrated be estimated by Ordinary Least Squares (OLS).

It will also been applied to Forescast Error Variance Decomposition (FEVD), which has as main objective the analysis of the variance of the error percentage caused by the shock of a variable in relation to other variables. The variance decomposition separates the variation of a variable with the endogenous component of the shocks in the VAR (lacoviello, 2009).

An analysis of the Impulse Response Functions (IRF) that present the impacts, from the shocks or innovations inherent to a particular variable that causes an impact on the other variables analyzed using standard error units in relation to each of the variables (Grenne, 2003).

\section{Results and discussion}

The analysis of the VAR part initially analyzing the error correction model and the statistical tests inherent to the model, however, it is necessary to define the number of lags $(p)$ for the model applied, so the lag tests are show in Table next.

Table 1. Order Selection Criteria.

\begin{tabular}{cccccc}
\hline Lag & LR & FPE & AIC & SC & HQ \\
\hline 0 & - & $9.89 \mathrm{E}-07$ & 0.362650 & 0.438564 & 0.393289 \\
1 & 2917.331 & $2.02 \mathrm{E}-12$ & -12.73627 & -12.28079 & -12.55244 \\
2 & 172.5420 & $1.13 \mathrm{E}-12$ & -13.32032 & $-12.48528^{*}$ & $-12.98330^{*}$ \\
3 & 70.14391 & $1.01 \mathrm{E}-12^{*}$ & $-13.43372 *$ & -12.21910 & -12.94350 \\
4 & $43.66537^{*}$ & $1.02 \mathrm{E}-12$ & -13.42554 & -11.83136 & -12.78212 \\
5 & 22.63700 & $1.14 \mathrm{E}-12$ & -13.31707 & -11.34333 & -12.52046 \\
\hline
\end{tabular}

* Indicates lag order selected by the criterion; LR: Sequential Modified LR Test Statistic; FPE: Final Prediction Error; AIC: Akaike Information Criterion; SC: Schwarz Information Criterion; HQ: Hannan-Quinn Information Criterion. Source and Development: Authors.

The indicates lags $(p)$ order selected by the criterion of shown in Table 1 indicated from the LR Test Statistics, the model should have four lags, while the FPE criterion and the AIC criterion, the model should have three lags. However, the SC and $\mathrm{HQ}$ criterions recommend that adopted two lags the model.

As the results differed in the number of suitable lags the model, it been accepted the number of lags indicated by $\mathrm{SC}$ and $\mathrm{HQ}$ criterions, because these criteria are more parsimonious. So, recommend two lags, so that the model involves the least possible parameters to be estimate and well explain the behavior of the response variable.

Table 2. Residual Serial Correlation LM Test.

\begin{tabular}{ccc}
\hline Lag & Statistics LM & p-value \\
\hline 1 & 85.06722 & 0.0000 \\
\hline 2 & 90.88568 & 0.0000 \\
\hline 3 & 27.69352 & 0.3222 \\
\hline 4 & 37.61834 & 0.0504 \\
\hline 5 & 30.44823 & 0.2079 \\
\hline 6 & 21.25195 & 0.6785 \\
\hline 7 & 32.12141 & 0.1545 \\
\hline 8 & 30.64560 & 0.2010 \\
\hline 9 & 58.24473 & 0.0002 \\
\hline
\end{tabular}

Source and Development: Authors. 
The results presented in Table 2 demonstrate that there is autocorrelation LM (Lagrange Multiplier) in VEC assemblies between the 3rd to 8th lags, because the null hypothesis that there is no serial correlation to the lag $h$ are not rejected, i.e., the probability value ( $p$-value) is greater than the $1 \%$ significance level. However, in the first, second and ninth lags, the result shows the existence of autocorrelation.

Table 3. Residual Normality Tests.

\begin{tabular}{cccccccccc}
\hline \multicolumn{2}{c}{ Residual Correlation (Doornik-Hansen) } & & \multicolumn{3}{c}{ Residual Covariance (Urzúa) } \\
\cline { 1 - 3 } \cline { 7 - 9 } Component & JB & df & p-value & & Component & JB & Df & p-value \\
\hline 1 & 142.9484 & 2 & 0.0000 & & 1 & 585.5429 & 2 & 0.0000 \\
\hline 2 & 16.79376 & 2 & 0.0002 & & 2 & 50.58093 & 2 & 0.0000 \\
\hline 3 & 130.7777 & 2 & 0.0000 & & 3 & 11870.38 & 2 & 0.0000 \\
\hline 4 & 44.05973 & 2 & 0.0000 & & 4 & 105.8662 & 2 & 0.0000 \\
\hline 5 & 53.44215 & 2 & 0.0000 & & 5 & 340.3584 & 2 & 0.0000 \\
\hline Joint & 388.0217 & 10 & 0.0000 & & Joint & 13829.49 & 105 & 0.0000 \\
\hline
\end{tabular}

Source and Development: Authors.

According to Table 3 , the residual normality tests for Residual Correlation (Doornik-Hansen) and Residual Covariance (Urzúa) demonstrated through the Jarque-Bera statistics (JB) that the null hypothesis of residual are multivariate normal not it can be rejected at a significance level of $1 \%$. Since the results presented by the p-values for multivariate normal distribution hypothesis are null for both multivariate unconditional returns, as well as for the standardization.

In order to verify the presence of long-term relationship between variables was performed Johansen Cointegration Test, using the trace statistic test and maximum eigenvalue, considering the presence of intercept in the integration vector.

Table 4. Johansen Cointegration Test.

\begin{tabular}{|c|c|c|c|c|c|c|c|c|c|}
\hline \multicolumn{5}{|c|}{ Test $\lambda$ trace } & \multicolumn{5}{|c|}{ Test $\lambda$ maximum } \\
\hline $\mathrm{H}_{0}$ & $\mathbf{H}_{1}$ & $\begin{array}{l}\text { Testing } \\
\text { Statistics }\end{array}$ & $\begin{array}{c}\text { Critical } \\
\text { Value } \\
95 \%\end{array}$ & $\begin{array}{c}\text { Critical } \\
\text { Value } \\
99 \%\end{array}$ & $\mathbf{H}_{0}$ & $\mathrm{H}_{1}$ & $\begin{array}{l}\text { Testing } \\
\text { Statistics }\end{array}$ & $\begin{array}{c}\text { Critical } \\
\text { Value } \\
95 \%\end{array}$ & $\begin{array}{c}\text { Critica } \\
\text { Value } \\
99 \%\end{array}$ \\
\hline$r=0$ & $r>0$ & $95.0345^{* *}$ & 68.52 & 76.07 & $r=0$ & $r=1$ & $42.6215^{* *}$ & 33.46 & 38.77 \\
\hline$r \leq 1$ & $r>1$ & $52.4130 *$ & 47.21 & 54.46 & $r=1$ & $r=2$ & 30.7989 * & 27.07 & 32.24 \\
\hline$r \leq 2$ & $r>2$ & 21.6140 & 29.68 & 35.65 & $r=2$ & $r=3$ & 14.9719 & 20.97 & 25.52 \\
\hline$r \leq 3$ & $r>3$ & 6.64210 & 15.41 & 20.04 & $r=3$ & $r=4$ & 4.64659 & 14.07 & 18.63 \\
\hline$r \leq 4$ & $r>4$ & 1.99550 & 3.76 & 6.65 & $r=4$ & $r=5$ & 1.99550 & 3.76 & 6.65 \\
\hline
\end{tabular}

** Null hypothesis rejected at significance level of $1 \%$; * Null hypothesis rejected at significance level of $5 \%, r=$ cointegration vector. Source and Development: Authors.

According to Table 4, the statistics for the test trace show that the null hypothesis that the cointegration vector is less than or equal to $1(r \leq 1)$ is rejected, at a significance level of $5 \%$ Thus, this result indicates that there is at least one cointegration vector that establish equilibrium in the long-run.

The test result of the maximum eigenvalue indicates that the null hypothesis that there is at most one vector of cointegration $(r=1)$ can be rejected at a significance level of $1 \%$, Therefore, it can be said that the test indicates that there are at most two cointegrating vectors to establish an equilibrium in the long-run. 
The results of the trace and maximum eigenvalue tests indicates rejection of the null hypothesis that there is no cointegration vector, and that there is an equilibrium relationship in the long run between the variables. The results indicated equivalent rejections; we opted for the use of the number of cointegrated equations defined by the stroke test statistically perceptible that there are two cointegrating vectors at $5 \%$.

With sensed to verify the stationarity of the series studied been applied to the unit root test with structural break proposed by Lanne et al. (2003).

Table 5. Unit Root Test with Structural Breaks.

\begin{tabular}{cccccc}
\hline \multirow{2}{*}{ Variables } & Model $^{\mathbf{a}}$ & Lags $^{\mathbf{b}}$ & ShiftFunction & $\begin{array}{c}\text { Used Break } \\
\text { Date }\end{array}$ & $\begin{array}{c}\text { Statistics } \\
\text { Test }^{\mathbf{c}}\end{array}$ \\
\hline \multirow{2}{*}{ LNV } & $\mathrm{C}$ & 2 & Impulse Dummy & $1999: 06$ & -4.7156 \\
\cline { 2 - 6 } & $\mathrm{C}, \mathrm{T}$ & 2 & Rational Shift & $2000: 02$ & -4.9274 \\
\hline \multirow{2}{*}{ LNM1 } & $\mathrm{C}$ & 4 & Impulse Dummy & $1997: 04$ & -8.3747 \\
\cline { 2 - 6 } & $\mathrm{C}, \mathrm{T}$ & 2 & Rational Shift & $1995: 07$ & -8.3692 \\
\hline \multirow{2}{*}{ LNIPCA } & $\mathrm{C}$ & 4 & Impulse Dummy & $1999: 08$ & -5.2912 \\
\cline { 2 - 6 } & $\mathrm{C}, \mathrm{T}$ & 2 & Rational Shift & $1995: 03$ & -5.2995 \\
\hline \multirow{2}{*}{ LNTXC } & $\mathrm{C}$ & 4 & Impulse Dummy & $1999: 04$ & -8.5781 \\
\cline { 2 - 6 } & $\mathrm{C}, \mathrm{T}$ & 2 & Rational Shift & $1995: 07$ & -8.5482 \\
\hline \multirow{2}{*}{ LNTXJ } & $\mathrm{C}$ & 4 & Impulse Dummy & $1995: 05$ & -4.7158 \\
\cline { 2 - 6 } & $\mathrm{C}, \mathrm{T}$ & 2 & Rational Shift & $1999: 04$ & -4.7001 \\
\hline
\end{tabular}

aModel "C" with constant and "T" with deterministic trend; blag value selected according to the criteria of SC; ${ }^{c}$ critical values with $1 \%$ significance level. Critical values of Saikkonen Lütkepohl-Test are (Lanne et al., 2002): (i) model with constant: $-3.48(1 \%) ;-2.88(5 \%)$ and $-2.58(10 \%)$; (ii) model with constant and deterministic trend: $-3.55(1 \%) ;-3.03(5 \%)$ and $-2.76(10 \%)$. Source and Development: Authors.

According to Table 5, the results of the unit root test proposed by Lanne et al. (2003) indicate that the variables analyzed in the study are stationary in level, i.e., the variables are integrated of order zero I (0).

Their structural breaks are conditioned the changes that occurred in the economy during the review period. The adoption of a floating exchange (LNTXC), there were changes in interest rates (LNTXJ) due to absorption of external shocks later, the interest rate was used as a control instrument of the inflation targeting regime (LNIPCA); added to the increase in loans and big fall of the spread (LNM1) and the Asian crisis (1997), Russian (1998) and Argentina (1999), caused changes in car sales in Brazil (LNV).

According to Enders (1995), the ordering of variables was performe based on block-exogeneity Granger test. The order follows the value of the chi-square statistic, wherein the exogenous variables, which have the lowest statistical values, are place before the endogenous variables.

The ordering of the variables defined by block-exogeneity Granger test unit had the following ordering: LNV; LNIPCA; LNM1; LNTXC and LNTXJ.

Table 6. Normalized Cointegration Coefficients.

\begin{tabular}{ccccc}
\hline LNV & LNIPCA & LNM1 & LNTXC & LNTXJ \\
\hline 1.000000 & -0.906766 & -2.352458 & 0.457557 & -0.273378 \\
\hline & $(0.15829){ }^{*}$ & $(0.42776)$ & $(0.27892)$ & $(0.28119)$ \\
\hline
\end{tabular}

*Standard error; Source and Development: Authors. 
Thus, the variables-balance in the long run in accordance with the values shown in Table 6, above. The results presented show that the signals are consistent with economic theory. The LNIPCA a negative result. This negative relationship is justified by the adoption of the price control mechanism, which were implement after the Real Plan, with the regime of inflation targeting.

The LNM1 show a negative value, which can be explained by the adoption of a restrictive monetary policy, in which the Brazilian National Treasury and Foreign Sector Operations were contractionary, coming at the expense of economic agents have increased the remittance of foreign currency, results to the uncertainties and turbulence of international crises. The LNTXC had a positive parameter, because to exchange rate appreciation, which occurred after the change of exchange rate regime, which discouraged car imports, resulting in an increase in production and sales of domestic vehicles.

The LNTXJ show a negative result due to reductions in the basic interest rate/SELIC, because to negative expectations by the market as the election and inauguration of a new president, coupled with the adoption of interest rast policy.

In order to observe the occurrence of a time precedence relationship between variables was used the test for Granger non-causality proposed by Toda \& Yamamoto (1995), which shows the capacity of a variable to assist in predicting behavior of another variable of interest. The result of Test for Granger Non-Causality for six lags are expose in Table 7 below.

Table 7. Test for Granger Non-Causality.

\begin{tabular}{lcc}
\hline Null hypothesis & $\boldsymbol{X}^{2}$ & Probability \\
\hline LNIPCA does not Granger cause LNV & 1.259001 & 0.5329 \\
\hline LNM1 does not Granger cause LNV & 2.376962 & 0.3047 \\
\hline LNTXC does not Granger cause LNV & 7.399163 & 0.0247 \\
\hline LNTXJ does not Granger cause LNV & 12.81416 & 0.0016 \\
\hline $\begin{array}{l}\text { LNIPCA, LNM1, LNTXC, LNTXJ does not Granger } \\
\text { cause LNV }\end{array}$ & 30.24162 & 0.0002 \\
\hline
\end{tabular}

Source and Development: Authors.

The results of Test Granger Non-Causality, point out that changes in LNIPCA, LNM1, LNTXC, and LNTXJ cause in the Granger, changes in LNV. These causal directions are significant at the $5 \%$ level. Therefore, the result indicates that the Brazilian price index, monetary aggregate, real effective exchange rate and real interest rate have an effect on car sales level.

The analysis of the variance decomposition allows you to check the error percentage of variance attributed to shocks between the variables studied, in this way, the variances decomposition assigned variables is exposed in the following Table: 
Table 8. Variance Decomposition.

\begin{tabular}{|c|c|c|c|c|c|c|}
\hline \multicolumn{7}{|c|}{ Variance Decomposition of LNV: } \\
\hline Period & Standard Error & LNV & LNIPCA & LNM1 & LNTXC & LNTXJ \\
\hline 1 & 0.058039 & 100.0000 & 0.000000 & 0.000000 & 0.000000 & 0.000000 \\
\hline 3 & 0.073855 & 91.55794 & 0.620679 & 1.745549 & 1.862147 & 4.213687 \\
\hline 6 & 0.085230 & 72.98994 & 1.287709 & 1.652563 & 14.98915 & 9.080635 \\
\hline 9 & 0.097555 & 56.14853 & 1.282262 & 1.377887 & 30.58836 & 10.60296 \\
\hline 12 & 0.101575 & 52.21150 & 1.294741 & 1.280428 & 34.13202 & 11.08131 \\
\hline \multicolumn{7}{|c|}{ Variance Decomposition of LNIPCA: } \\
\hline Period & Standard Error & LNV & LNIPCA & LNM1 & LNTXC & LNTXJ \\
\hline 1 & 0.279742 & 0.705552 & 99.29445 & 0.000000 & 0.000000 & 0.000000 \\
\hline 3 & 0.329253 & 1.050470 & 92.09138 & 0.000667 & 6.684401 & 0.173080 \\
\hline 6 & 0.347274 & 1.086134 & 91.01208 & 0.028714 & 7.432339 & 0.440731 \\
\hline 9 & 0.352889 & 1.122921 & 89.65705 & 0.138141 & 7.872560 & 1.209329 \\
\hline 12 & 0.355294 & 1.174326 & 88.82269 & 0.148974 & 8.040283 & 1.813732 \\
\hline \multicolumn{7}{|c|}{ Variance Decomposition of LNM1: } \\
\hline Period & Standard Error & LNV & LNIPCA & LNM1 & LNTXC & LNTXJ \\
\hline 1 & 0.015778 & 0.785501 & 0.686359 & 98.52814 & 0.000000 & 0.000000 \\
\hline 3 & 0.033615 & 1.190196 & 0.799769 & 95.55700 & 1.481766 & 0.971267 \\
\hline 6 & 0.040027 & 7.955590 & 3.469094 & 77.18648 & 5.314649 & 6.074184 \\
\hline 9 & 0.043825 & 7.486102 & 4.100906 & 72.14870 & 7.404268 & 8.860028 \\
\hline 12 & 0.046033 & 6.860369 & 3.790291 & 66.05549 & 13.85665 & 9.437197 \\
\hline \multicolumn{7}{|c|}{ Variance Decomposition of LNTXC: } \\
\hline Period & Standard Error & LNV & LNIPCA & LNM1 & LNTXC & LNTXJ \\
\hline 1 & 0.037143 & 7.420499 & 0.054974 & 0.011128 & 92.51340 & 0.000000 \\
\hline 3 & 0.085531 & 4.917530 & 0.238871 & 0.116849 & 94.11917 & 0.607585 \\
\hline 6 & 0.103303 & 3.679736 & 0.477913 & 0.264716 & 95.01767 & 0.559963 \\
\hline 9 & 0.104030 & 3.988669 & 0.519213 & 0.474947 & 94.22148 & 0.795692 \\
\hline 12 & 0.104389 & 3.994388 & 0.540748 & 0.607855 & 93.69146 & 1.165554 \\
\hline \multicolumn{7}{|c|}{ Variance Decomposition of LNTXJ: } \\
\hline Period & Standard Error & LNV & LNIPCA & LNM1 & LNTXC & LNTXJ \\
\hline 1 & 0.115475 & 0.341089 & 2.520817 & 1.166805 & 0.362823 & 95.60847 \\
\hline 3 & 0.159751 & 6.236027 & 1.444465 & 2.274755 & 1.670200 & 88.37455 \\
\hline 6 & 0.202614 & 11.80283 & 2.826634 & 1.607292 & 2.180792 & 81.58245 \\
\hline 9 & 0.228995 & 11.79856 & 3.965379 & 1.423096 & 4.312208 & 78.50075 \\
\hline 12 & 0.249198 & 11.09778 & 4.317415 & 1.226100 & 9.013082 & 74.34563 \\
\hline \multicolumn{7}{|c|}{ Cholesky Ordering: LNV LIPCA LNM1 LTXC LNTXJ } \\
\hline
\end{tabular}

Source and Development: Authors.

Based on Table 8, the variance decomposition of LNV shows that the end of twelve months, approximately $52 \%$ of the variance in the number of sales is explained by the index itself; about $1.3 \%$ is explained by LNIPCA; about $11 \%$ by LNTXJ; little more than $1.2 \%$ by LNM 1 and are explained more than $34 \%$ by LNTXC.

The variance decomposition of LNM1 indicates that the end of the period, approximately $66 \%$ of variance explained by the index itself; about $7 \%$ by LNV is explained; approximately $3.8 \%$ by LNIPCA; little more than $9 \%$ by LNTXJ and more than $13 \%$ by LNTXC. 
The result of the variance decomposition of LNIPCA explains that the end of twelve months, about $88 \%$ of variance explained by the index itself; about $1 \%$ by LNV is explained; little more than $8 \%$ by LNTXC; about $0.1 \%$ by LNM 1 are explained and less than $1.9 \%$ by LNTXJ.

The values of the variance decomposition of shows that the above LNTXC period just over $93 \%$ of the exchange rate of the variance explained by the index itself; about $0.5 \%$ is explained by LNIPCA; about $4 \%$ by LNV; for $0.6 \%$ by LNM 1 and just over $1 \%$ by LNTXJ.

The analysis of variance decomposition of LNTXJ indicates that the end of twelve months, approximately $74 \%$ of variance explained by the index itself; slightly more than $11 \%$ and is explained by LNV little more than $1 \%$ by LNM 1 are explained; about $9 \%$ by LNTXC; and just over $4 \%$ are explained by LNIPCA.

Thus, the level of car sales are more likely explanations of the variance of the real effective exchange rate and real interest rate than the variances of the monetary aggregate and Brazilian price index.

Based on these results, derived is the impulse response functions of the main variables of interest. The purpose of this type of function is to show how the endogenous variables of the VEC behave when there is a shock in a specific endogenous variable.

The impulse response shows the behavior of the variables resulting from a shock innovation another variable. Thus, in response to a shock innovation variables by estimating VEC are distribute in the following Figures 1-5.

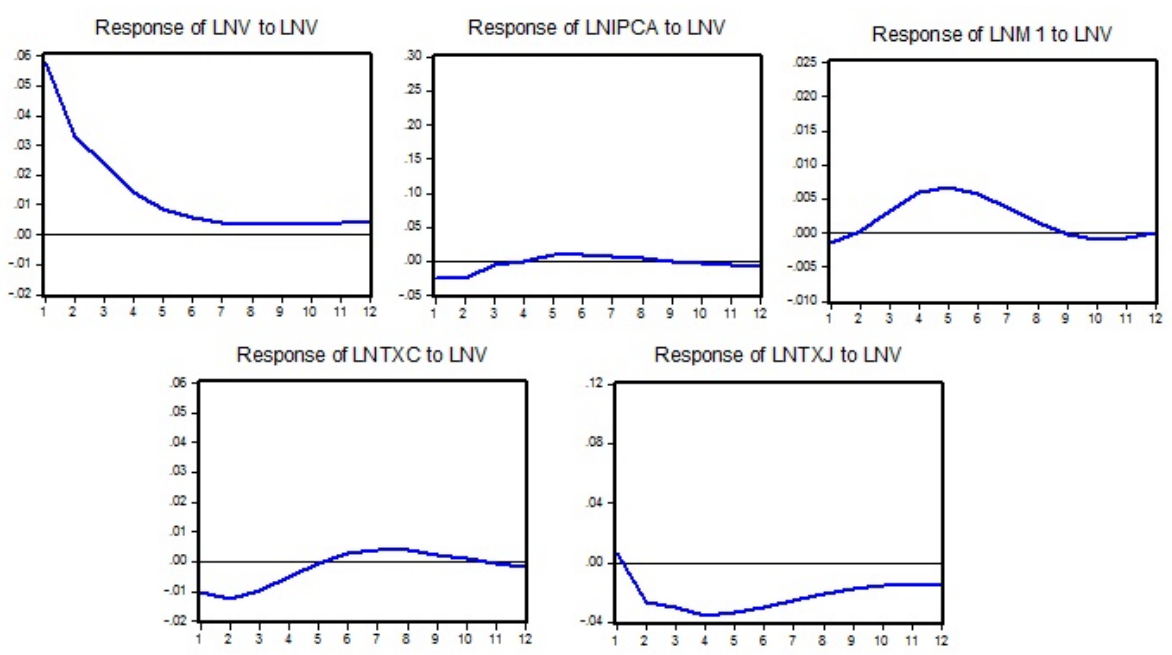

Figure 1. Response of Impulse in the number of Car Sales. Source and Development: Authors.

As shown in Figure 1, a shock in the LNV standard deviation results in an increase in LNM1 between the second and the eighth month, the fifth month the peak at about $0.006 \%$. It also occurs a slight decrease, which reaches $0.01 \%$ in the first five months in LNTXC. A shock of innovation in car sales, because a negative result in LNTXJ over the entire period. An impact on LNIPCA, resulting from a shock in car sales, brings in a small increase between the second and eighth month, reaching $0.006 \%$ apex in the fifth month of the stipulated period. 


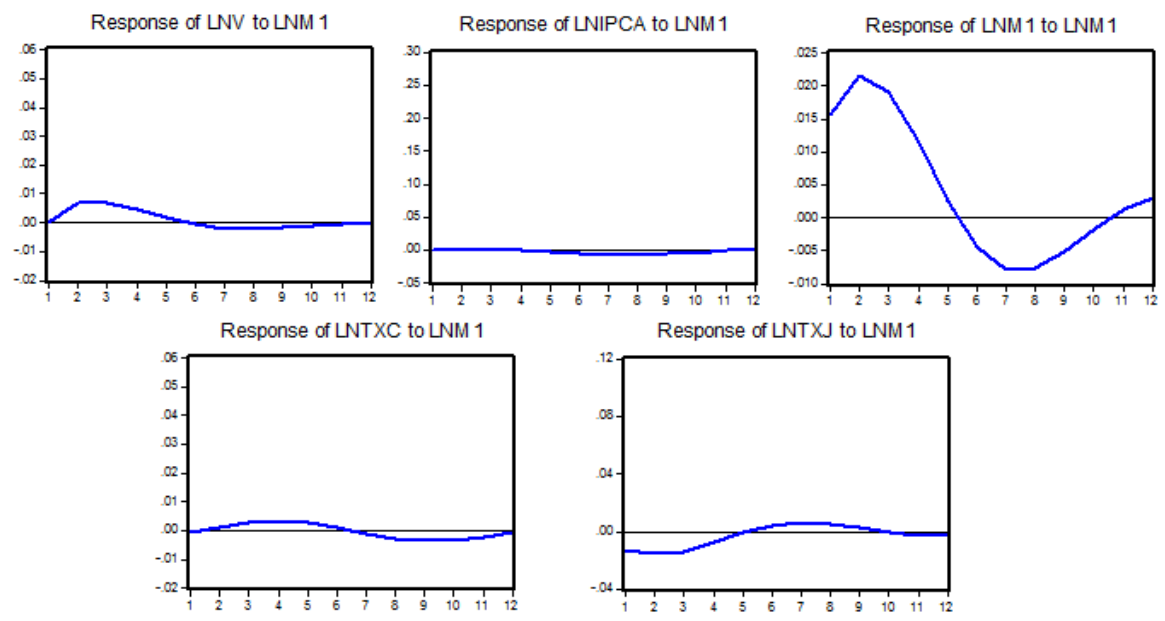

Figure 2. Response of Impulse in Monetary Aggregate. Source and Development: Authors.

As shown in Figure 2, the answer of an unexpected shock in LNM1 cause an increase of about 0.006 percentage points in LNV in the third month of the period, after the fifth month, this effect is reversed, it becomes negative. A shock in the monetary aggregate causes a decline in LNIPCA during the third to the eleventh month.

An impact on LNTXJ, caused by a shock in the monetary aggregate, causes in a first moment a negative response in more than -0.015 percentage points in the second month, however, there is an increased response in the sixth month, the positive levels until the tenth month. An impulse in monetary aggregate cause's positive response in LNTXC, this response reaches a maximum of 0.003 percentage points, remaining positive until the sixth month, negative for the rest of the period.

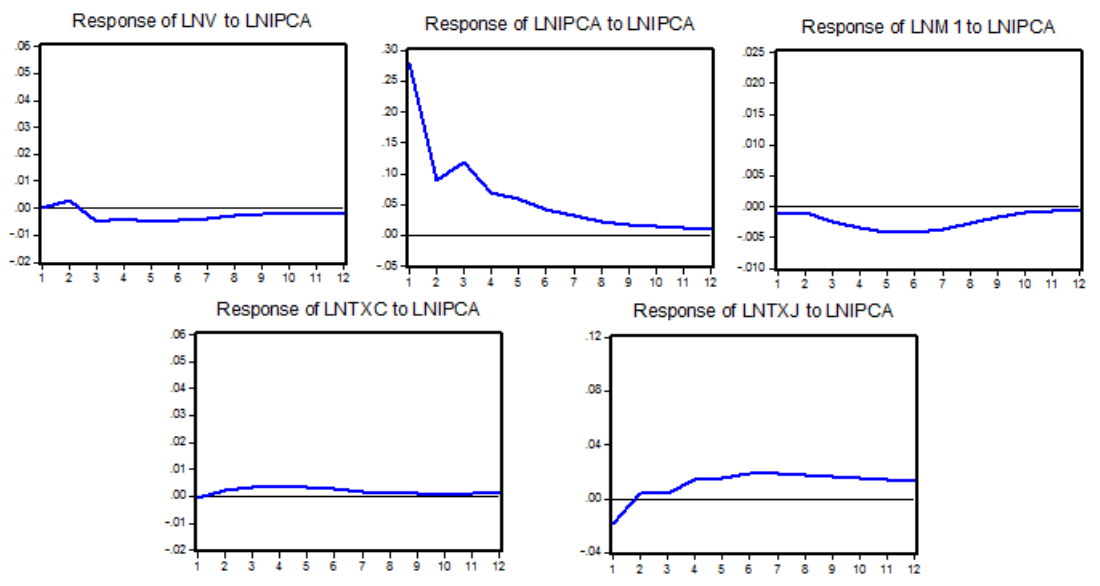

Figure 3. Response of Impulse in the Internal Price Index. Source and Development: Authors.

According to Figure 3, an unexpected shock in LNIPCA, causes in a first instant a positive response in the LNV, however, during the third period end his answer was negative in up -0.005 p.p. An impact on the index price causes a negative result in approximately -0.004 percentage points LNM1, between the fifth and sixth month. 
The behavior of LNTXC result of a shock to the internal price index, comes into positive values that reach 0.003 percentage points. Already, the response to an impulse in internal price index, resulting in a first moment, in a negative effect on LNTXJ in about $-0.01 \%$, however, the results become positive over the remaining period reaching more than 0.01 p.p.

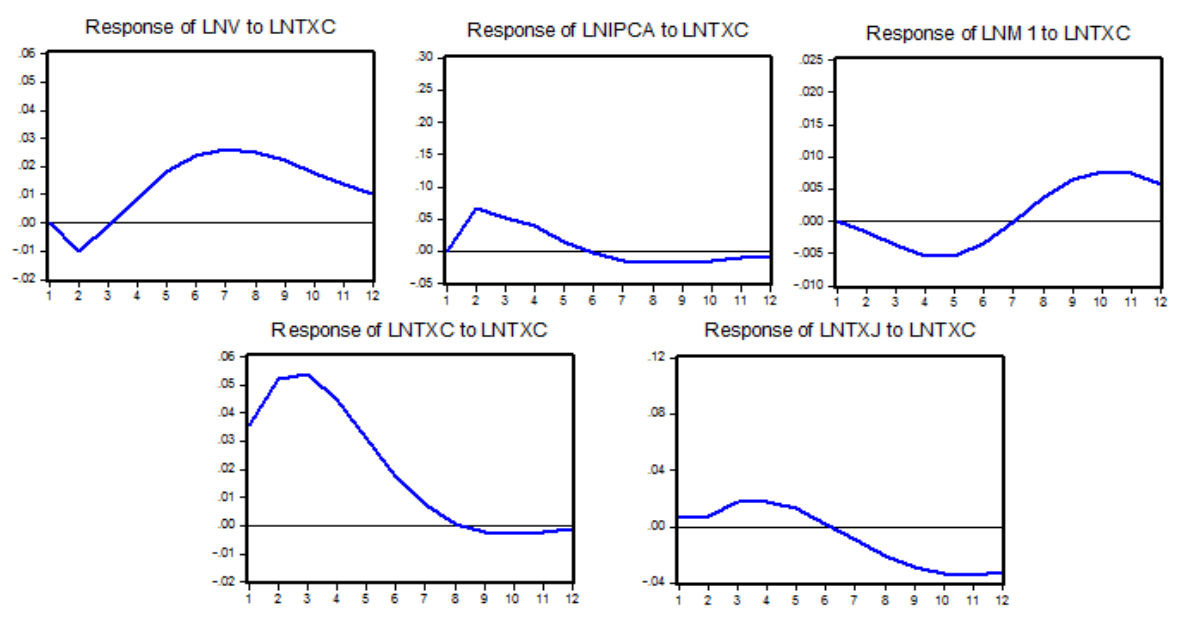

Figure 4. Response of Impulse in the Real Effective Exchange Rate. Source and Development: Authors.

According to Figure 4, an unexpected impulse in LNTXC, results in first instant negative values in LNV, however, the fourth month, the result of the shock is positive, reaching its peak of approximately $0.03 \%$ in the seventh month. The response to an innovation shock in the real effective exchange rate causes up to six months, a negative effect on LNM1, however, on the effect becomes positive settling at values of $0.008 \mathrm{p}$. $\mathrm{p}$.

An innovation in the real effective exchange rate has a positive impact on LNIPCA, reaching its peak in the second month, by more than 0.06 percentage points. Already an innovation shock in the real effective exchange rate results in a positive effect of approximately $0.01 \%$ in LNTXJ after this maximum result, there is a retreat from the seventh to the end of the period to -0.03 percentage points.

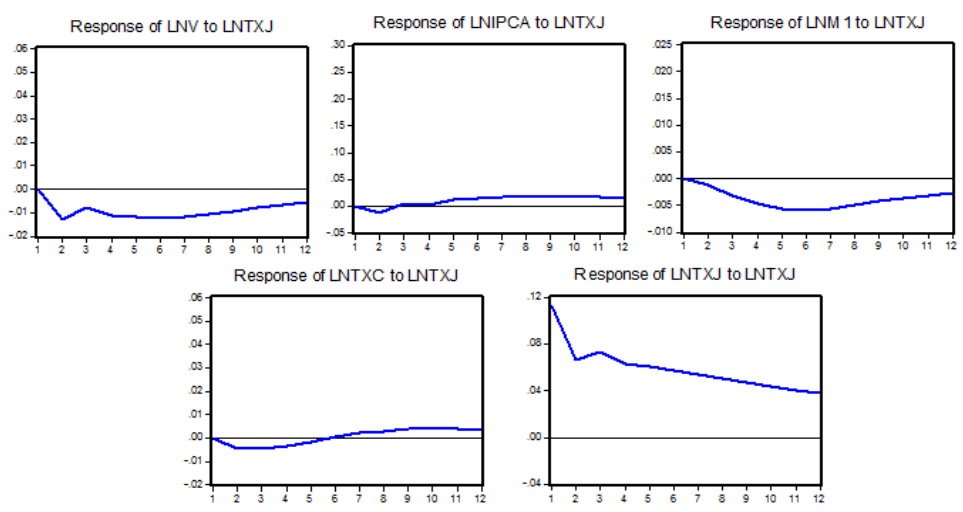

Figure 5. Response of Impulse in the Real Interest Rate. Source and Development: Authors. 
According to Figure 5, a shock standard deviation in LNTXJ results in a negative impact on LNV, with its apex in the second month in -0.013 percent. The result of a shock in the real rate of interest on LNM1 has a negative effect over the entire period, with its lower values, between the fifth and seventh months, approximately $-0.005 \%$.

With a standard deviation shock in the real interest rate leads to a positive, result in LNIPCA, near 0.02 percentage points, between the eighth and ninth months. Already, the effect on LNTXC as a result of a shock in the real interest rate entails, first, a negative result in $0.004 \%$, however, the sixth month onwards, the results were positive by 0.004 percentage points in the tenth month.

The results point the response of impulse that car sales level are more prone to innovation shocks in the real effective exchange rate and the real rate of interest than standard deviation of innovations in other variables.

\section{Conclusions}

This study aims to assess the impact of monetary policy on vehicle sales, a horizon of analysis January 1995 to December 2014, taking into account as macroeconomic variables for monetary policy: the monetary aggregate, the internal price index, the rate of real effective exchange rate and the real interest rate.

The cointegration test shows that the trace and maximum eigenvalue tests indicated that there are at least two statistically noticeable cointegration vectors at the level of $5 \%$, an equilibrium relationship in the long run between the variables. The equilibrium parameters in the long run show a positive relationship between real effective exchange rate with auto sales; while the other variables showed a negative relationship.

Granger Non-Causality analysis showed a temporal precedence relation between the variables, and changes in the monetary aggregate in the domestic price index, the real effective exchange rate and real interest rates cause changes in the number of sales automobiles, and are statistically significant at the $5 \%$ level.

The results of the Forescast Error Variance Decomposition ensure that, over twelve months, the estimated errors of car sales is explained by the index itself $52.21 \%$; and $1.29 \%$ are explained by the internal price index; $11.08 \%$ for the real rate of interest, $1.28 \%$ by monetary aggregate $34.13 \%$ and the real effective exchange rate. Thus, the real interest rate and the real effective exchange rate are the macroeconomic variables that have greater significance in the car sales forecast error variance decomposition.

The behavior of car sales given a unit shock in the real interest rate causes a reduction in car sales number, over the period. A shock to the domestic price index reduces the number of car sales; have an impulse in real effective exchange rate, results in negative values in auto sales numbers during the period. A standard deviation shock in the monetary aggregate has a positive effect on car sales number. These results are robust and show that the monetary policy variables behave expected, according to economic theory. The estimation of the VEC model and the graphs of the behavior of the variables studied are arranged in the appendices (Appendix A-B)

Thus, based on the estimated results, it can ensure that monetary policy variables defined monetary aggregate, the domestic price index, the rate of real effective exchange rate and the real rate of interest, provide effects in auto sales in Brazil. Its effects are rapid, significant and consistent. The results of this study are consistent with the searched by Arquete \& Jayme (2003), Ireland (2005); Fernandes \& Toro (2005) and Tomazzia \& Meurer (2009). 
The article is limited only find the monetary aggregate, the domestic price index, the rate of real effective exchange rate and the real interest rate as monetary policy mechanisms, not analyzing other endogenous or exogenous variables, or tax policies can cause changes in car sales in Brazil. Thus, it is suggest that future studies might look at other variables of monetary policy and other macroeconomic policies in different periods to this study.

\section{References}

Arquete, L. C. R., \& Jayme, F. G., Jr. (2003). Política monetária, preços e produto no Brasil (1994-2002): uma aplicação de vetores auto-regressivos. In Anais do XXXI Encontro Nacional de Economia da ANPEC. Niterói: ANPEC.

Banco Central do Brasil - BACEN. (1999). Relatório de inflação. 1(1). Retrieved in 2015, October 13, from https://www.bcb.gov.br/?id=RI\&ano=1999

Banco Central do Brasil - BACEN. (2004). Contas nacionais. Retrieved in 2015, October 13, from http://saladeimprensa,ibge,gov,br/noticias?view=noticia\&id=1\&busca=1\&idnoticia=2329

Barboza, R. M. (2015). Taxa de juros e mecanismos de transmissão da política monetária no Brasil. Revista de Economia Política, 35(1), 133-155. http://dx.doi.org/10.1590/010131572015v35n01a08.

Casotti, B. P., \& Goldenstein, M. (2008). Panorama do setor automotivo: as mudanças estruturais da indústria e as perspectivas para o Brasil. BNDES Setorial, 28, 147-188. Retrieved in 2017, October 12, from http://www.bndes.gov.br/SiteBNDES/export/sites/default/bndes_pt/Galerias/Arquivos/conhe cimento/bnset/set2806.pdf

Enders, W. (1995). Applied econometric time series. New York. John Wiley \& Sons.

Fernandes, M., \& Toro, J. (2005). O mecanismo de transmissão monetária na economia brasileira pós-plano real. Revista Brasileira de Economia, 59(1), 5-32. http://dx.doi.org/10.1590/S0034-71402005000100001.

Grenne, W. H. (2003). Econometric analysis (7th ed.). New Jersey: Pretice Hall.

lacoviello, M. (2009). Macroeconomic theory II. Massachusetts: Boston College.

Ireland, P. N. (2005). The monetary transmission mechanism. Boston: Federal Reserve Bank of Boston. Working Paper Nº6-1. Retrieved in 2017, October 12, from http://www.bos.frb.org/economic/wp/index.htm

Lanne, M., Lutkepohl, H., \& Saikkonen, P. (2002). Comparison of unit root tests for time series with level shifts. Journal of Time Series Analysis, 23(6), 667-685. http://dx.doi.org/10.1111/1467-9892.00285.

Lanne, M., Lutkepohl, H., \& Saikkonen, P. (2003). Test procedures for unit roots in time series with level shifts at unknown time. Oxford Bulletin of Economics and Statistics, 65(1), 91115. http://dx.doi.org/10.1111/1468-0084.00036.

Mendonça, H. F. (2001). Mecanismos de transmissão monetária e a determinação da taxa de juros: uma aplicação da regra de Taylor ao caso brasileiro. Economia e Sociedade (Campinas), (16), 65-81. Retrieved in 2017, January 5, from www.eco.unicamp.br/docprod/downarq.php?id=520\&tp=a

Modenesi, A. M. (2010). Política Monetária no Brasil pós Plano Real (1995-2008): um breve retrospecto. Economia \& Tecnologia, 6(21), 21-30. Retrieved in 2017, January 5, from https://revistas.ufpr.br/ret/article/view/26987/17996

Pacheco, L. M. M. A. D. (2006). O mecanismo de transmissão da política monetária: o papel dos preços dos activos (Tese de doutorado). Universidade Técnica de Lisboa, Portugal. 
Saikkonen, P., \& Lütkepohl, H. (2002). Testing for a unit root in a time series with a level shift at unknown time. Econometric Theory, 18(2), 313-348. http://dx.doi.org/10.1017/S0266466602182053.

Santos, A. M. M. M., \& Burity, P. (2002). O complexo automotivo. Rio de Janeiro: BNDES. Retrieved in 2017, January 5, from http://www.bndes.gov.br/SiteBNDES/export/sites/default/bndes_pt/Galerias/Arquivos/conhe cimento/livro_setorial/setorial06.pdf

Toda, H. Y., \& Yamamoto, T. (1995). Statistical inference in vector autoregressions with possibly integrated processes. Journal of Econometrics, 66(1-2), 225-250. http://dx.doi.org/10.1016/0304-4076(94)01616-8.

Tomazzia, E. C., \& Meurer, R. (2009). O mecanismo de transmissão da política monetária no Brasil: uma análise em VAR por setor industrial. Economia Aplicada, 13(4), 371-398. http://dx.doi.org/10.1590/S1413-80502009000400002. 
Appendix A. Estimates VEC.

$\mathrm{D}(\mathrm{VNF})=-0.02125669711 *(\mathrm{LNV}(-1)-\mathrm{LNIPCA} 0.9095091402 *(-1)-$ 2.368647889 * LNM1 $(-1)+0.4596368532$ LNTXC * $(-1)-0.2850837228$ LNTXJ * $(-1)$ $+0.2849568647)-0.4120292859$ * $\mathrm{D}(\mathrm{LNV}(-1))-0.329341729$ * D (LNV (-2)) $0.01240187289 \mathrm{D}$ * $($ LNIPCA (-1)) $-0.02884086021 \mathrm{D}$ * $($ LNIPCA $(-2))+0.3670399342$ * D (LNM1 (-1)) + $0.09980131135 \mathrm{D}$ * (LNM1 (-2)) -0.2474245072 * D (LNTXC (-1)) + $D$ * $0.2639757464($ LNTXC (-2)) - 0.1039765224 * D (LNTXJ (-1)) -0.0337284708 * $D$ $($ LNTXJ $(-2))+0.002636280035$ 


\section{Appendix B. Graphs of the variables.}
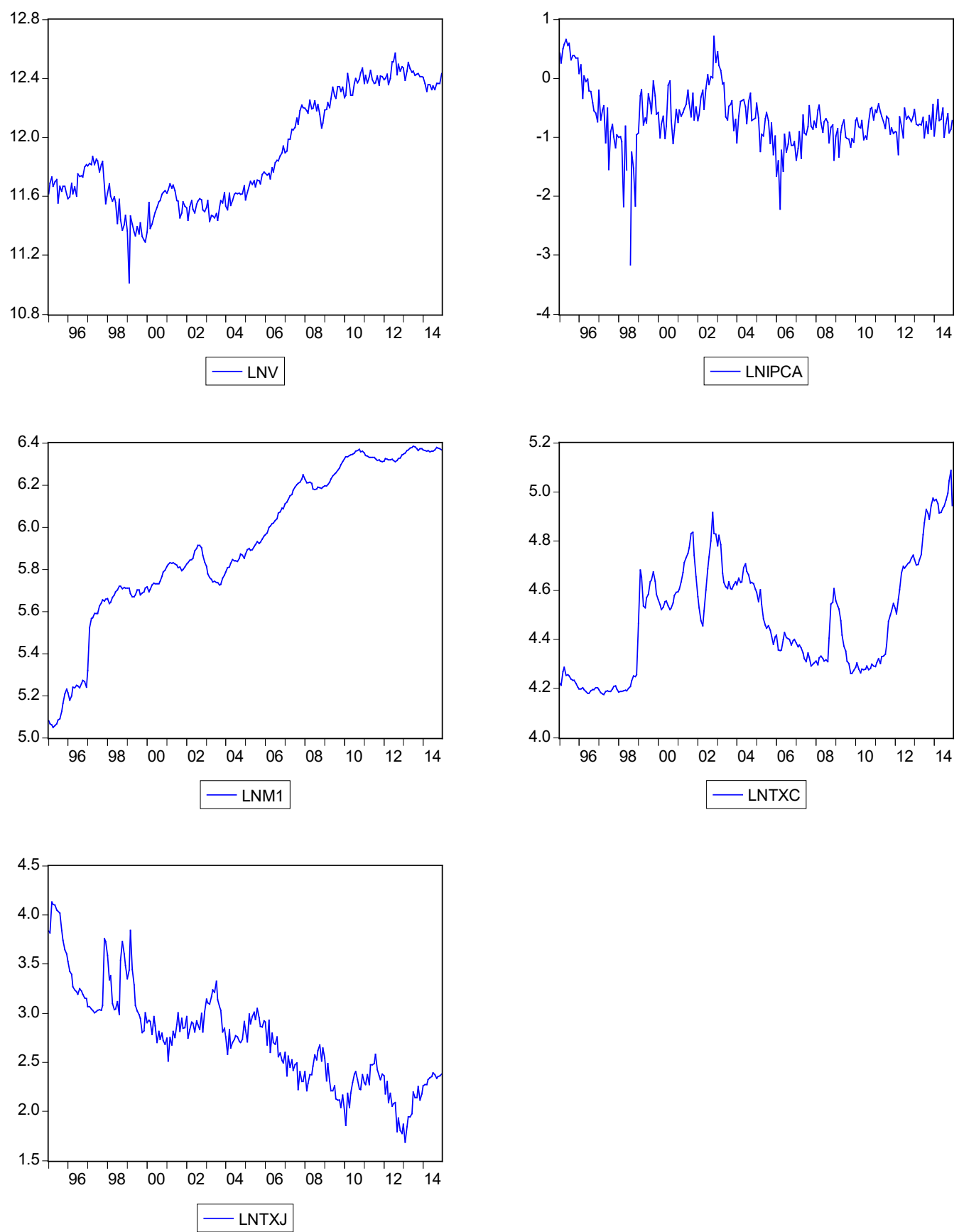